\title{
Affirmative Action Model in Strengthening the Education Rights Protection and Fulfillment of Person with Disability
}

\author{
Irwansyah Reza Mohamad $^{1}$, Ismet Hadi $^{1}$ \\ ${ }^{1}$ Department of Law, Muhammadiyah University of Gorontalo, Indonesia
}

\begin{abstract}
The uncertainty of legal regulations on the fulfillment of education rights for persons with disabilities creates serious problems. The absence of special arrangements causes overlapping responsibilities which will result in not being integrated into programs that support the educational needs of persons with disabilities. This problem requires the seriousness of local governments to provide protection and fulfillment of education rights for persons with disabilities. This study aims to determine the legal policy for the Protection and Fulfillment of the Right to Education and to formulate an affirmative action model for the protection and fulfillment of the education rights of persons with disabilities in the future. This study uses empirical legal research, namely research that initially examines secondary data, then continues with research on primary data through interview data collection. The results of the research show that local governments still seem to have not fully provided protection and fulfillment of the rights of persons with disabilities to adequate education so that they face various kinds of discrimination, even though there are regulations at the level of the 1945 Constitution of the Republic of Indonesia and laws that have guaranteed it. Second, regulations at the level of Regional Regulations in Gorontalo Province have not reached the lateness of fulfilling the right to education both inclusively and specifically in a systematic and comprehensive manner. It is necessary to have a legal reform in the form of affirmative policies in the field of education for persons with disabilities.
\end{abstract}

Keywords: Persons with Disabilities, Affirmative Action Model, Educational Right

Received: December 27, 2020

Revised: January 1,2020

Accepted: January 4, 2021

\section{Introduction}

So far, the alignments of the national education system have not paid much serious attention to people with disabilities. People with disabilities are those who have different abilities, not as usual. Their different abilities are often considered odd, so that the state also provides educational services that are still odd. They have the same rights before the law. Their constitutional rights are guaranteed in the 1945 Constitution of the Republic of Indonesia. One of the rights of Persons with Disabilities is education as described in Article 5 paragraph (1) letter e of Law Number 8 Year 2016 concerning Persons with Disabilities.

Law Number 20 of 2003 concerning the National Education System in Article 5 paragraph (1) states that: every citizen has the same right to obtain quality education. The fulfillment of the right to education for persons with disabilities in Gorontalo City has not been maximized because it is not supported by needs-based arrangements. Uncertainty in legal arrangements on the fulfillment of the right to education of persons with disabilities creates serious problems. This is because without any special regulation it causes overlapping responsibilities which will result in not being integrated into programs that support the educational needs of persons with disabilities.

The absence of a special regional regulation that regulates persons with disabilities causes overlapping programs and activities across Regional Work Units (SKPD). Another thing that 
is no less important is related to the fulfillment of education for people with disabilities is the improvement of facilities and infrastructure as well as the regional budget for revenue which is devoted to encouraging the necessary needs. On the other hand, the challenge for the Gorontalo city government is regarding the distribution and equalization of the needs of teachers and students with disabilities that are not supported by existing legal policies. The efforts made by the Gorotantalo city government are equalizing and adjusting the program. Adjusting the inclusive education curriculum for persons with disabilities is the most important agenda for local governments to harmonize existing education programs.

Affirmative action or positive discrimination can be justified constitutionally. With the existence of constitutional rights, every citizen has constitutional guarantees for each of his rights as stated in the 1945 Constitution of the Republic of Indonesia. This guarantee can be in the form of the embodiment of constitutional rights into law or the provision of space for constitutional challenges to the Constitutional Court if there is a violation of these rights. citizens' rights (Hamidi, 2016). Such arrangements are the same as in the Indian Constitution which implements a "reservation" system to elevate backward classes in the education and social sector based on Article 15 paragraph (4) and Part IV regarding the "Directive Principles of State Policy" of the Indian Constitution (Sayuti, 2013 ).

Basically, affirmative action is a discriminatory policy, even though it is seen as a positive discrimination genre because it is only temporary in nature in order to open up opportunities for certain groups of people to gain the same opportunities that have been enjoyed by other groups of society. In practice, it is known that laws or policies imposed on certain groups are in the form of granting privileges or special treatment in certain cases (Griadhi, 2020). This study aims to determine the legal policy for the Protection and Fulfillment of the Right to Education for Persons with Disabilities in Gorontalo City and to formulate an affirmative action model for the protection and fulfillment of the education rights of persons with disabilities in the future.

\section{Methods}

Empirical legal research is research that initially examines secondary data, then continues with research on primary data in the field, or on society (Soekanto, 2006). The type of research that prospective researchers use is empirical legal research because this research is conducted by directly examining the field in order to obtain real, factual data. According to Fajar \& Achmad (2010) research location is very necessary for legal research, especially for empirical legal research. This is different from legal research which is normative in nature where research is clearly carried out in various libraries. The location of research in empirical legal research must be adjusted to the title and problem.

Legal research entitled Affirmative Action Model in the Framework of Strengthening the Protection and Fulfillment of the Education Rights of Persons with Disabilities in Gorontalo City. The data and information needed in this research will be obtained from the Gorontalo City Government which includes the Gorontalo City Education Office, the Gorontalo City Social and Community Empowerment Service, the Legal Section of the Regional Secretariat of the Gorontalo Province Regional Government. Data obtained directly from the public is called primary data, while data obtained from library materials is called secondary data. The types and sources of data used by prospective researchers in preparing this legal research include: Primary data is data obtained and collected directly from the field which is the object of research or obtained through interviews.

Data collection techniques in a descriptive study are an important part because they will be used to obtain complete and appropriate data. Prospective researchers hope to provide a 
complete and comprehensive picture of the Affirmative Action Model in the Context of Strengthening the Protection and Fulfillment of Educational Rights for Persons with Disabilities in Gorontalo City.

\section{Results and Discussion}

\section{Implementation of Policies on the Protection and Fulfillment of the Rights to Education of Persons with Disabilities in Gorontalo City}

Gorontalo City was designated as the capital of Gorontalo Province on February 16, 2001 based on Law Number 38 of 2000 concerning the Establishment of Gorontalo Province. Gorontalo City has an area of $66.25 \mathrm{~km} 2(0.55 \%$ of the area of Gorontalo Province) and has a population of 180,127 people with a population density of 2,719 people / km2. Gorontalo City has the motto "Adat with Syara", Syara "with Kibabullah" as a community view of life that combines customs and religion (Law Number 19 Year 2011).

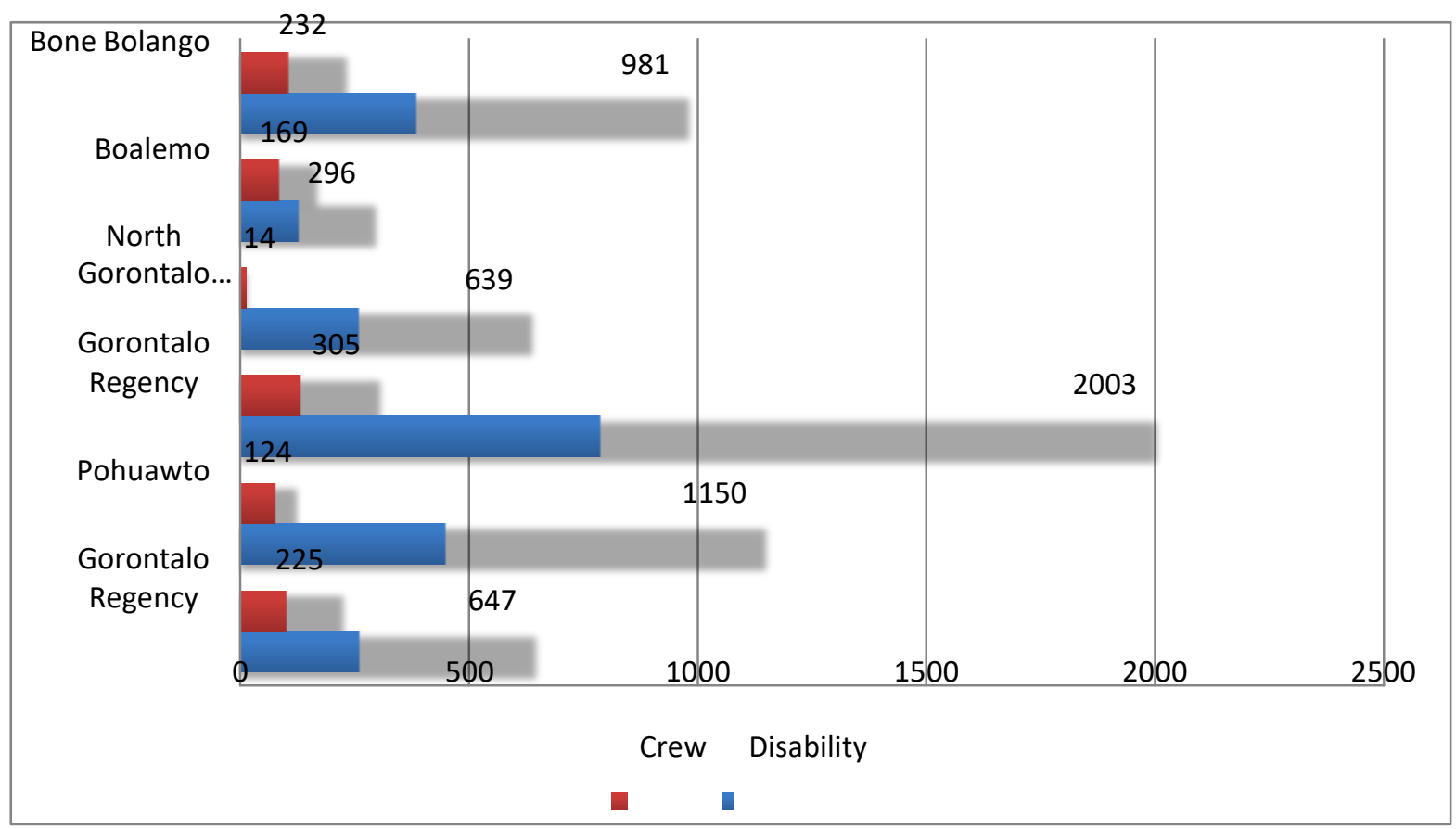

Figure 1. Disability Data from Regions

Source: Gorontalo Province Social Affairs 2019.

Of the total population of Gorontalo Province people, there are 5,816 people with disabilities who need adequate services. However, the number of institutions dealing with disabilities is still constrained in reaching most of the people with disabilities who live in rural areas and are far from the reach of mobile social rehabilitation and services that are part of the Social Service for Women's Empowerment and Child Protection (Dinsos P3A) program in Gorontalo Province. Fulfillment of the rights and needs of persons with disabilities by Dinsos P3A in accordance with Law Number 11 of 2009 concerning Social Welfare and Law Number 8 of 2016 concerning Persons with Disabilities.

In general, the number of people with disabilities in Gorontalo City is somewhat less than the number in other districts in Gorontalo Province. Fulfillment of the basic needs of persons with disabilities including education, health and welfare is carried out in an integrated manner by several related agencies in the city of Gorontalo. What is an obstacle in fulfilling the rights of persons with disabilities in almost all regions in Indonesia is due to data collection or administration of population of vulnerable people such as persons with disabilities. Most 
local government policies in meeting basic needs such as adequate education, health and welfare as well as planned and budgeted programs/activities depend on the suitability of population data collection for persons with disabilities in the regions.

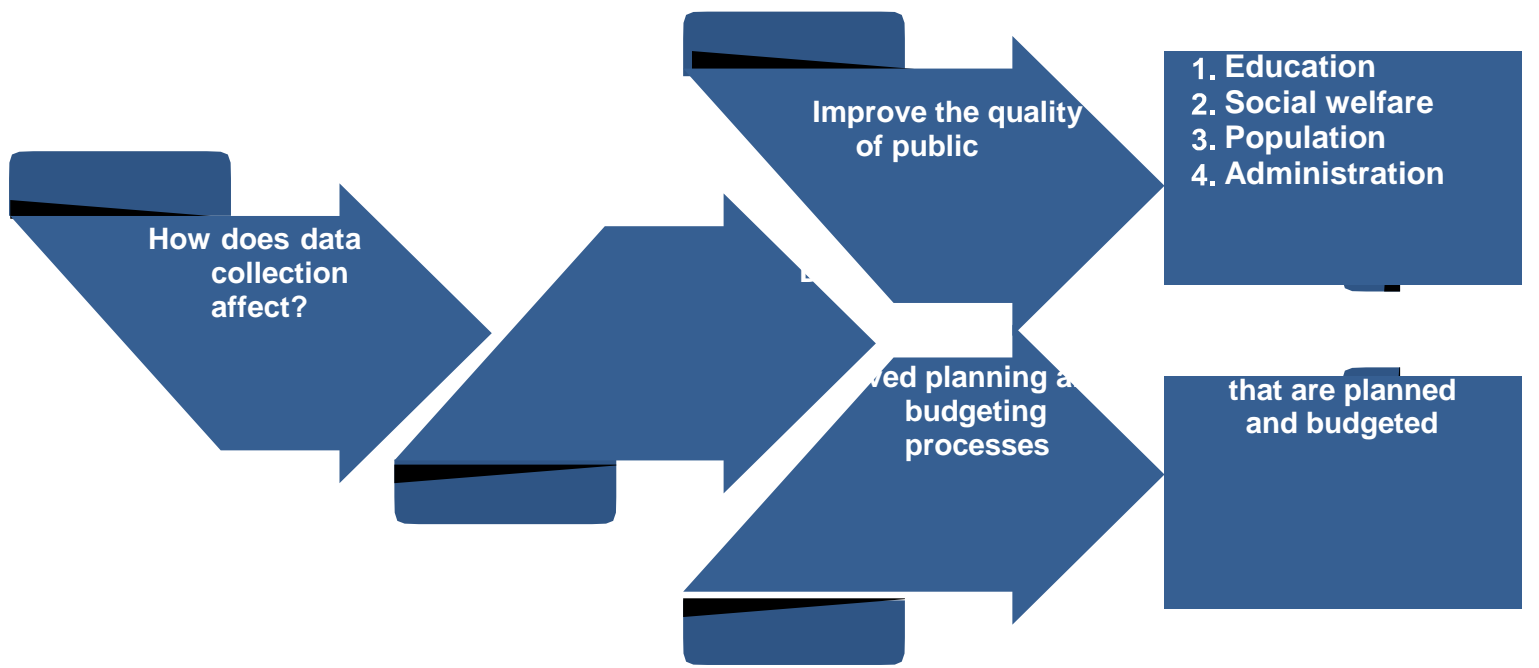

Figure 2. Frame Disability Data Collection Innovation

Source: Sudarno et al., (2019) Disability Data Collection Innovation.

Currently, at least the Ministry of Social Affairs, Ministry of Health, and the Central Statistics Agency (BPS) have recorded data on persons with disabilities in Indonesia. Data discrepancies have the potential to make it difficult for the central and regional governments to make policies. Until now, efforts to fulfill and protect the rights of persons with disabilities in Gorontalo Province have not been made in the form of regional regulations. For example, in other provinces such as South Kalimantan Province, South Kalimantan Provincial Regulation Number 4 of 2019 concerning Protection and Fulfillment of Rights of Persons with Disabilities is an example. This regional regulation was made as an order by Law Number 8 of 2016 concerning Persons with Disabilities in the provisions of Article 27 paragraph (1) which states that: "The Government and Regional Governments are required to plan, administer and evaluate the implementation of respect, protection and fulfillment of the rights of persons with disabilities". This also needs to be done by the local government in Gorontalo Province. It needs to remember that the existence of people with disabilities still often experiences various forms of discrimination so that their rights have not been fulfilled (Hadi, 2019).

So far the Gorontalo provincial government has made efforts to ensure education for persons with disabilities by issuing Gorontalo Governor Regulation Number 31 of 2015 concerning the Implementation of Inclusive Education in Gorontalo Province. This regulation aims to implement the provisions in Article 6 paragraph (3) of the Regulation of the Minister of National Education Number 70 of 2009 concerning Inclusive Education for students with disabilities and potential intelligence and / or special talents. Inclusive education in this Pergub is carried out in educational units ranging from PAUD (Early Age Education), SD / MI (Elementary School), SMP / MTs (Junior School), SMA / SMK (High School), MA / MAK (State Islamic High School) both public and private. Article 5 paragraph (1) in this Pergub regulates that: "Every sub-district in a district / city has at least 1 (one) PAUD, 3 (three) SD / MI, and 1 (one) SMP / MTs that provide inclusive education. "And paragraph (2) that:" every district / city has at least 1 (one) SMA / SMK / MA / MAK that provides inclusive education". 
Based on the provisions of this article, the government has made efforts to ensure that inclusive education can be implemented in all districts / cities. The obstacle that then occurs is whether the provisions in Article 7 that: "every education unit that provides inclusive education in all education units is obliged to accept students with special needs" and Article 8: "every education unit that will provide inclusive education at least meets the following requirements. : (a) special tutors are available who can provide learning programs for students with special needs; and (b) available facilities and infrastructure for students with special needs as well as paying attention to accessibility and / or supporting the needs of students". The availability of special educators / supervising teachers and the availability of infrastructure and facilities based on the needs of students with special needs (Article 8), as well as a special curriculum (Article 10) must also be fulfilled with the provisions in this Governor Regulation.

Table 1. Number of Education Units in Gorontalo Province

\begin{tabular}{|c|l|c|c|c|c|c|c|c|c|c|c|c|c|c|}
\hline No & Regency/City & $\begin{array}{c}\text { Elementary } \\
\text { School }\end{array}$ & $\begin{array}{l}\text { Junior } \\
\text { School }\end{array}$ & $\begin{array}{c}\text { High } \\
\text { School }\end{array}$ & $\begin{array}{c}\text { Vocational } \\
\text { School }\end{array}$ & TOTAL & & & & & & & \\
\hline & $\mathbf{N}$ & $\mathbf{S}$ & JML & $\mathbf{N}$ & $\mathbf{S}$ & JML & $\mathbf{N}$ & $\mathbf{S}$ & $\mathbf{J M L}$ & $\mathbf{N}$ & $\mathbf{S}$ & JML & \\
\hline 1 & $\begin{array}{l}\text { Gorontalo } \\
\text { City }\end{array}$ & 100 & 22 & 122 & 17 & 14 & 31 & 8 & 8 & 16 & 5 & 4 & 9 & 178 \\
\hline 2 & $\begin{array}{l}\text { Gorontalo } \\
\text { Regency }\end{array}$ & 289 & 43 & 332 & 122 & 29 & 151 & 19 & 15 & 34 & 7 & 7 & 14 & 531 \\
\hline 3 & $\begin{array}{l}\text { Pohuwato } \\
\text { Regency }\end{array}$ & 125 & 16 & 141 & 43 & 13 & 56 & 8 & 8 & 16 & 8 & 4 & 12 & 225 \\
\hline 4 & $\begin{array}{l}\text { Bone } \\
\text { Bolango } \\
\text { Regency }\end{array}$ & 131 & 13 & 144 & 39 & 13 & 52 & 9 & 6 & 15 & 6 & 1 & 7 & 218 \\
\hline 5 & $\begin{array}{l}\text { North } \\
\text { Gorontalo } \\
\text { Regency }\end{array}$ & 135 & 13 & 148 & 45 & 9 & 54 & 10 & 4 & 14 & 4 & 2 & 6 & 22 \\
\hline 6 & $\begin{array}{l}\text { Boalemo } \\
\text { Regency }\end{array}$ & 135 & 12 & 147 & 57 & 9 & 66 & 12 & 5 & 17 & 10 & 0 & 10 & 240 \\
\hline \multicolumn{2}{|l|}{ TOTAL } & 915 & 119 & 1034 & 323 & 87 & 410 & 66 & 46 & 112 & 40 & 18 & 58 & 1614 \\
\hline
\end{tabular}

Source: Gorontalo Education Office 2015/2016

Table 2. Number of Education Units Organizing Inclusive Education in Gorontalo

\begin{tabular}{|c|c|c|c|c|c|}
\hline No & Regency/City & $\begin{array}{c}\text { Elementary } \\
\text { School }\end{array}$ & Junior School & $\begin{array}{c}\text { High } \\
\text { School }\end{array}$ & Total \\
\hline 1. & Gorontalo City & $\begin{array}{l}\text { Elementary School } \\
\text { NO 61 Kota Timur } \\
\text { North City } 102 \\
\text { Public Elementary } \\
\text { School } \\
\text { Maes Christian } \\
\text { Public Elementary } \\
\text { School }\end{array}$ & $\begin{array}{l}\text { Junior High } \\
\text { School 6, } \\
\text { Gorontalo City } \\
\text { Junior High } \\
\text { School 8, } \\
\text { Gorontalo City } \\
\text { SP3 Association, } \\
\text { Gorontalo City }\end{array}$ & $\begin{array}{c}\text { Senior } \\
\text { High } \\
\text { School 3, } \\
\text { Gorontalo } \\
\text { City }\end{array}$ & 7 \\
\hline 2. & $\begin{array}{l}\text { Gorontalo } \\
\text { Regency }\end{array}$ & $\begin{array}{l}\text { Public Elementary } \\
\text { School } 1 \\
\text { LIMBOTO } \\
\text { Public Elementary } \\
\text { School } 2 \text { TALAGA } \\
\text { Public Elementary }\end{array}$ & $\begin{array}{l}\text { Junior High } \\
\text { School } 2 \\
\text { LIMBOTO } \\
\text { Junior High } \\
\text { School } 1 \\
\text { BATUDAA }\end{array}$ & - & 9 \\
\hline
\end{tabular}




\begin{tabular}{|c|c|c|c|c|c|}
\hline & & $\begin{array}{l}\text { School } 7 \\
\text { BATUDAA } \\
\text { Public Elementary } \\
\text { School } 7 \\
\text { TABONGO } \\
\text { Public Elementary } \\
\text { School } 6 \text { TELAGA } \\
\text { JAYA }\end{array}$ & $\begin{array}{l}\text { Junior High } \\
\text { School } 1 \\
\text { LIMBOTO } \\
\text { Junior High } \\
\text { School } 2 \\
\text { BATUDAA }\end{array}$ & & \\
\hline 3. & Pohuwato Regency & $\begin{array}{l}\text { Public Elementary } \\
\text { School } 3 \\
\text { PATILANGIO } \\
\text { Public Elementary } \\
\text { School } 2 \\
\text { PENTADU } \\
\text { Public Elementary } \\
\text { School } 4 \\
\text { PATILANGGIO }\end{array}$ & $\begin{array}{l}\text { Junior High } \\
\text { School } 1 \\
\text { PAGUAT } \\
\text { Junior High } \\
\text { School 1 } \\
\text { RANDANGAN }\end{array}$ & - & 5 \\
\hline 4. & $\begin{array}{l}\text { Bone Bolango } \\
\text { Regency }\end{array}$ & $\begin{array}{l}\text { Public Elementary } \\
\text { School } 1 \text { KABILA } \\
\text { Public Elementary } \\
\text { School } 3 \text { BONE }\end{array}$ & $\begin{array}{l}\text { Junior High } \\
\text { School } 1 \\
\text { KABILA }\end{array}$ & - & 3 \\
\hline 5. & $\begin{array}{l}\text { North Gorontalo } \\
\text { Regency }\end{array}$ & $\begin{array}{l}\text { Public Elementary } \\
\text { School } 1 \\
\text { TOLONGIO } \\
\text { Public Elementary } \\
\text { School 1 NORTH } \\
\text { BUNTULIA } \\
\text { Public Elementary } \\
\text { School 1 KOTAJIN } \\
\text { Public Elementary } \\
\text { School 1 } \\
\text { GENTUMA } \\
\text { RAYA }\end{array}$ & $\begin{array}{l}\text { Junior High } \\
\text { School } 2 \\
\text { SUMALATA } \\
\text { Junior High } \\
\text { School } 2 \text { BIAU } \\
\text { Junior High } \\
\text { School 1 } \\
\text { GENTUMA } \\
\text { RAYA }\end{array}$ & & 7 \\
\hline 6 & Boalemo Regency & $\begin{array}{l}\text { Public Elementary } \\
\text { School } 3 \\
\text { BOYUMOITO }\end{array}$ & $\begin{array}{l}\text { Junior High } \\
\text { School 1 } \\
\text { BOTUMOITO } \\
\end{array}$ & & 2 \\
\hline \multicolumn{4}{|c|}{ TOTAL } & 33 & \\
\hline
\end{tabular}

Source: Ministry of Education and Culture 2020

Based on existing data, the Gorontalo city government has implemented inclusive education as stipulated in Article 5 Gorontalo Governor Regulation Number 41 of 2015. Inclusive education is itself a strategy of the Gorontalo city government to reduce or even eliminate restrictions or obstacles in accessing education for children with special needs. The fact that children with special needs still face rejection when enrolling in public schools. This is in line with what the Secretary of the Gorontalo City Education Office, Mr. Yanson and Mrs. Oneng, employees who work at the Gorontalo City Ordinary Large School (SLB) state that the school is still arguing on the grounds that the limited teaching staff and facilities and infrastructure are inadequate, plus not yet effective special curriculum for the education of children with disabilities in public schools. This is of course a serious problem for the 
Gorontalo city government to fulfill its commitment in planning, supervision, and budgeting for the sake of the implementation of quality education in accordance with existing laws.

Apart from providing inclusive education, the Gorontalo city government has also guaranteed the implementation of special education for persons with disabilities through the existence of the Gorontalo City Special School (SLB). The purpose of special schools is generally to provide services to persons with disabilities who have physical, mental and social psychological disabilities so that they are able to develop optimally through education and can be independent according to their abilities so that they can become useful members of society for themselves, their families and society.

Table 3.Data of SLB Gorontalo City T.A 2019/2020 students

\begin{tabular}{|l|c|c|c|c|c|c|}
\hline \multirow{2}{*}{\multicolumn{1}{|c|}{ Type of Disability }} & \multicolumn{2}{|c|}{ SDLB } & \multicolumn{2}{c|}{ SMPLB } & \multicolumn{2}{c|}{ SMALB } \\
\cline { 2 - 7 } & M & F & M & F & M & F \\
\hline Blind & 3 & 2 & - & 1 & 1 & 1 \\
\hline Deaf & 16 & 17 & 9 & 6 & 3 & 6 \\
\hline Light Mentally disabled & 32 & 29 & 35 & 25 & 7 & 7 \\
\hline $\begin{array}{l}\text { Medium Mentally } \\
\text { disabled }\end{array}$ & 15 & 5 & 1 & 3 & 5 & 4 \\
\hline Tuna Daksa & 8 & 6 & 2 & 1 & 2 & 3 \\
\hline Amount & 74 & 59 & 47 & 36 & 23 & 11 \\
\hline Total & & \multicolumn{7}{|c}{245 People } \\
\hline
\end{tabular}

Source: Gorontalo City Special School 2020

From the available data, it can be seen that almost all children with special needs from groups of persons with disabilities have almost entirely taken education through special school education institutions and very few have received inclusive education at existing public schools. This has increasingly made it difficult for persons with disabilities to blend in and be accepted by society in general. Therefore, there needs to be a set of affirmative policies to ensure the fulfillment and protection of the law for persons with disabilities in obtaining and strengthening their education rights, as well as encouraging the community to be integrated together to give more attention for the creation of a just and prosperous Gorontalo city community.

\section{Affirmative Action in Fulfilling and Protecting the Right to Education for Persons with Disabilities in Gorontalo City}

To overcome the problems faced by persons with disabilities in obtaining the right to education as mandated by the 1945 Constitution of the Republic of Indonesia, it is necessary to carry out a further regulation according to legal needs in society. Affirmative Action or affirmative policy is an effort to solve the problem of discrimination by the state against persons with disabilities. Starting from the guarantee of equal opportunities for persons with disabilities to get proper education services at all levels of education regulated by Law Number 8 of 2016, it is necessary to elaborate through implementing regulations such as government regulations, presidential regulations, ministerial regulations and regional regulations. Affirmation policies as positive discrimination can open spaces for people with disabilities to get the same opportunities and opportunities as those enjoyed by other groups of normal society (Hall, 2004; Jahoda \& Markova, 2004; Milner \& Kelly 2009). 
In practice, there are laws or policies imposed on certain groups in the form of granting privileges or special treatment in certain cases. From a human rights perspective, affirmation policy is known as a specific measure in the context of fulfilling rights comprehensively so that there is substantive equality so that the affirmation policy becomes a correction, assistance and compensation for discriminatory and unfair treatment experienced by persons with disabilities.

Affirmative policies in the framework of protecting and fulfilling the education rights of persons with disabilities, especially in Gorontalo City, have not been seen and felt by those with special needs. Researchers when being a resource person at the Open Discussion Forum on the occasion of International Disability Day involving the Putra Mandiri Gorontalo Foundation, the Gorontalo Province Social and Employment Service, Gorontalo Province Radio Republik Indonesia (RRI) and Students of the Muhammadiyah University of Gorontalo and the community found the problems faced by people with urban disabilities Gorontalo includes, among other things, minimal participation of persons with disabilities and lack of affirmation from both regulatory and practice aspects at the provincial / district / city and village levels towards regional development planning and budgeting, particularly in increasing accessibility, participation, control and benefits for persons with disabilities. This is due to the fact that budgeting for persons with disabilities is still the task and function of certain Regional Apparatus Organizations (OPD) such as the Social Service, even though the fulfillment of the rights of persons with disabilities is a cross-sector obligation such as health, education, public works, civil registration, economy, and others. This is of course a serious problem that needs the attention of the Gorontalo city government, all stakeholders and the community.

The regional government according to the 1945 Constitution of the Republic of Indonesia has the authority to stipulate regional regulations and other regulations in the context of implementing autonomy and assistance tasks. The absence of a regional regulation that specifically regulates persons with disabilities in Gorontalo City is certainly a question and an assumption that there is a lack of efforts to protect and fulfill the rights of persons with disabilities in Gorontalo City. But so far the Gorotanlo government has attempted to protect and fulfill the right to education for persons with disabilities through Gorontalo Governor Regulation Number 41 of 2015 concerning the Implementation of Inclusive Education in Gorontalo Province. This Pergub is an implementing regulation of the Minister of National Education Regulation Number 70 of 2009 concerning Inclusive Education. The purpose of this Pergub is to provide inclusive education for students who have physical, emotional, mental and social disabilities, or have the potential for intelligence and / or special talents to obtain useful education in accordance with their needs and opportunities and to realize nondiscriminatory education. This Pergub is an example of affirmative action policies in the world of education in the form of inclusive education, but the reality of implementation has not matched expectations, starting from planning and budgeting that have not supported people with disabilities as students, there are not many educators / teachers who have communication skills, and the infrastructure not disability friendly and inadequate curriculum.

From the results of observations and analysis of existing problems, the researcher tries to formulate an affirmative policy model that can be used as input for the Gorontalo city government to strengthen the protection and fulfillment of education rights for persons with disabilities.

Compiling accurate data on persons with disabilities (by name by address) from each hamlet, village, sub-district, to regency / city. This data collection activity is carried out in a 
participatory manner by the Social Service together with the Central Statistics Agency which can involve community members, Organizations for Persons with Disabilities and PwDs in the local area. The results of the data collection are then consolidated by various parties such as BPS, local government and regional apparatus organizations so as to produce a single data that becomes a reference for stakeholders in the effort to fulfill rights such as education and others.

The involvement or participation of persons with disabilities in making policies related to public services such as educational services tailored to children with special needs, starting with the participation room for persons with disabilities and related parties in the mechanism for preparing service standards in preparing draft service standards, discussing service standards, providing feedback or input. against the draft service standard which aims to improve the design by the operator.

Strengthening the Disability Service Unit as mandated by Law Number 8 of 2016 concerning Persons with Disabilities mandates a policy for local governments to provide a Disability Service Unit that functions as a service provider and facilities or as a resource center such as a place to increase the competence of educators and education personnel in regular schools in handling children with special needs, providing assistance to children with special needs in supporting the smooth learning process, developing compensatory programs, providing learning media and tools that people with disabilities need as students, implementing early detection and early intervention for students and prospective students with disabilities, providing data and information on disabilities, providing consultation services and developing cooperation with other parties or institutions in an effort to improve the quality of education for students with disabilities litas (Pawestri, 2017).

The Gorontalo city government ensures that inclusive education runs optimally by providing Special Assistance Teachers in the acceptance of ASN, besides that there is a need for training programs for teachers on inclusive education that are continuously developed and supported by adequate infrastructure and learning curriculum in the implementation of inclusive education itself.

\section{Conclusion}

Based on the discussion that has been previously described, the researchers can draw conclusions, among others: first, the regional government still seems not to have fully provided protection and fulfillment of the rights of persons with disabilities to adequate education so that various kinds of discrimination arise against them, even though there are regulations at the level of the Constitution. NRI of 1945 and the law that has guaranteed it. Second, regulations at the level of Regional Regulations in Gorontalo Province have not reached the lateness of fulfilling the right to education both inclusively and specifically in a systematic and comprehensive manner. It is necessary to have a legal reform in the form of affirmative policies in the field of education for persons with disabilities.

\section{References}

Fajar, M. N. D., \& Achmad, Y. (2010). Dualisme Penelitian Hukum: Normatif \& Empiris. Pustaka Pelajar.

Griadhi, N. M. A. Y. (2020). Affirmative Action Untuk Peningkatan Kesetaraan Bagi Kaum Disabilitas Tunarungu Dalam Pemenuhan Hak Menikmati Acara Televisi. Vyavahara Duta, 14(2), 64-73.

Hadi, I. (2019). Urgensi Aksesibilitas Disabilitas Pada Instansi Pemerintahan Kabupaten Gorontalo. Jurnal Al Himayah, 3(2), 223-245. 
Hall, E. (2004). Social geographies of learning disability: narratives of exclusion and inclusion. Area, 36(3), 298-306.

Hamidi, J. (2016). Perlindungan Hukum terhadap Disabilitas dalam Memenuhi Hak Mendapatkan Pendidikan dan Pekerjaan. Jurnal Hukum Ius Quia Iustum, 23(4), 652671.

Jahoda, A., \& Markova, I. (2004). Coping with social stigma: People with intellectual disabilities moving from institutions and family home. Journal of intellectual disability research, 48(8), 719-729.

Milner, P., \& Kelly, B. (2009). Community participation and inclusion: People with disabilities defining their place. Disability \& Society, 24(1), 47-62.

Pawestri, A. (2017). Hak Penyandang Disabilitas dalam Perspektif HAM Internasional dan HAM Nasional. Era Hukum-Jurnal Ilmiah Ilmu Hukum, 15(1).

Sayuti, H. (2013). Hakikat Affirmative Action dalam Hukum Indonesia (Ikhtiar Pemberdayaan yang Terpinggirkan). MENARA, 12(1), 41-47.

Soekanto, S. (2006). Pengantar penelitian hukum. Penerbit: Universitas Indonesia, UI-Press.

Sudarno, Rohidin., \& Utomo, S. D. (2018). Inovasi Pendataan Disabilitas. Jakarta: PATTIRO. 